\title{
POSITIONING HALALAN TOYYIBAN IN HALAL FOOD SYSTEM: PRODUCTION, PROCESSING, CONSUMPTION, MARKETING, LOGISTIC AND WASTE MANAGEMENT
}

\author{
SYIFA' ZAINAL ARIFIN, ANIS NAJIHA AHMAD, YUMI ZUHANIS HAS-YUN HASHIM*, \\ NUR HANIE MOHD LATIFF, HARUNA BABATUNDE JAIYEOBA, NURHUSNA \\ SAMSUDIN AND NORSABRINA MOHD SAID \\ International Institute for Halal Research and Training (INHART), International Islamic University \\ Malaysia (IIUM), Jalan Gombak, 53100 Kuala Lumpur, Malaysia. \\ *Corresponding author: yumi@iium.edu.my
}

(Received: $1^{\text {st. }}$ May. 2021, Accepted: $19^{\text {th }}$ Jul. 2021, Published on-line: $26^{\text {th }}$ Jul. 2021)

\begin{abstract}
The halal food industry is founded based on the concept of Halalan Toyyiban (HT), as commanded in the Qur'an. However, as reflected in the current halal standards, requirements, and practices, the current approach of HT may overlook some components that are supposed to be an integral part of the concept. This article utilises the modern food system approach to frame the discussion for a holistic overview that links the cycle of the current food system and the $H T$ concept towards obtaining its conceptual clarity. The attributes of $H T$ in six different components of the established food system - production, distribution, processing, marketing, consumption and waste recovery; are contextualized. An explicit conceptual clarity of $H T$ shall create a ripple effect towards a change of mindset and behaviour of all stakeholders leading to the attainment of the wholesomeness of $H T$. Beyond the conceptual clarity, $H T$ attributes can be elegantly positioned in the modern food system as vehicles to provide safe, high quality, good and wholesome food; in an ethical and sustainable ecosystem.
\end{abstract}

KEYWORDS: Halal; Toyyiban; Halal food consumption; Halal lifestyle; Conceptual clarity

\section{INTRODUCTION}

The halal food industry continues to develop and grow, catering to consumers increasing demand for halal products and services. According to DinarStandard (2020), this lucrative market has raised by $3.1 \%$ in 2019 from $\$ 1.13$ trillion to $\$ 1.17$ trillion and slightly decreased in 2020 , before estimating for a skyrocketing to reach $\$ 1.38$ trillion in 2024 at a 5-year Cumulative Annual Growth Rate (CAGR) of $3.5 \%$. This positive trend is good news to Muslim consumers as there will be more options and alternatives for halal products in the market. The halal food industry is founded based on the concept of Halalan Toyyiban (HT), as commanded in the Qur'an. The holistic concept contains guidelines for the production and consumption of food according to Syari'ah (Islamic law). 
While halal products and services, in general, are often marketed as hygienic, wholesome, and environmental and animal-friendly (Bonne \& Verbbonneeke, 2008), the halal food industry also tends to overlook the integral toyyib aspects, (Liow, 2016). Under the current Malaysian Halal standards (MS 1500: 2019) and certification scheme, toyyib is, at best, only associated with hygienic preparation of food or production of safe food; still far from being holistic or wholesome as many have perceived or marketed. Under the scheme, foods that contribute lots of calories, higher in fat, cholesterol and sodium such as junk food and fast food, can still be certified as halal, although these foods could have negative health implications to the public. While the importance of halal and ensuring its integrity throughout the supply chain has gained interest by the stakeholders (Soon et al., 2017), toyyib, the complementary yet integral halal element, has not received comparable attention. This has been repeatedly pointed out by different authors, (Abdullah, 2018; Mohamad, 2019; Siddiqui, 2014). Siddiqui (2014), argued that “...as more [halal] information is known and shared, and as more [halal] knowledge is gained, the emphasis will move towards 'toyyib' or wholesome".

Halalan Toyyiban is a holistic concept associated with safe, fairly traded, and sustainability traits (Rezai et al., 2015). Hashim and Mohd Salleh (2020), suggested a large continuum of what constitutes toyyib in the scope of food and beverages, which may include hygiene, food safety, and safe and moderate use of food additives organic, ethical, environmentally friendly, and sustainable practices. HT aims to fulfil the physical and spiritual needs, (Haqqi, 2017), which is only achievable when the concept is holistically applied and practiced, both at consumers and the industrial level. The elucidations of religious principles into the actual exercise or practice vary, (Eagle \& Dahl, 2015) depend on the religiosity level and country. While many studies have found that customers are willing to put extra efforts and money to purchase halal certified food, (Awan et al., 2015), the toyyib factors, such as the food nutritional element, animal welfare, or sustainable packaging, are less considered in their purchase decision.

As such, this article aims to analyse the $H T$ attributes in the quest to attain its conceptual clarity. In this article, it is argued that while the concept of HT is syari'ah-grounded, it must shine through and stand out as being universal and practical. To identify the fundamental characteristics or key attributes that reflect $H T$, this article utilises the food system approach to frame the discussion for a holistic overview that links the cycle of the current food system and the $H T$ concept.

The concept of HT must be discussed and understood. The concept refers to "cognitive symbols (or abstract terms) that specify the features, attributes, or characteristics of the phenomenon in the real or phenomenological world that they are meant to represent and that distinguish them from other related phenomena", (Podsakoff et al., 2016). A clear concept shall guide both scholars and practitioners to expand research, applications and practices. Academically, conceptual clarity is important to avoid disagreement and uncertainty on supposedly 'similar' terms that may refer to distinct phenomena. Clarity helps operationalization of the concepts, for further analysis of their practical application. Clarity provides researchers with a common language to communicate ideas, thus, promoting mutual understanding. For practitioners, a better understanding of commonly used terms can enhance their practices. For policymakers, conceptual clarity is required to initiate strategies or plan to successfully implement and promote a specific initiative.

The article contextualizes the attributes of $H T$ in six different components of the established food system - production, distribution, processing, marketing, consumption and waste recovery. This concept could then be further developed to suggest intervention for the promotion of behavioural changes among consumers and industrial practices in the future. This article consists of seven sections. The subsequent section focuses on a brief description of the established 
conventional food system, followed by a discussion on the literal meanings of halal and toyyib. Next, the concept of $H T$ is described in general before deliberating $H T$ in more detail based on the six components of the food system.

\subsection{Food System}

The food system perspective has been used frequently in discussing nutrition, food, health, community economic development, and agriculture, (Sobal et al., 1998). This concept has been used in different contexts to assess and improve different production targets, such as food security, (Bellotti et al., 2018), rural wealth creation, local food strengthening, (Hinrichs, 2000), environmental change, (Ericksen, 2008), nutrition improvement, (Combs, 2000; Sobal et al., 1998) and sustainable food, (Faurès et al., 2013; Maretzki \& Tuckermanty, 2007). For instance, in a sustainable food context, a food system approach is used by the Food and Agriculture Organization (FAO) to design effective, proactive and sustainable climate-smart agriculture interventions, Faurès et al., 2013).

A food system approach looks at the "entire range of actors and their interlinked value-adding activities involved in the production, aggregation, processing, distribution, consumption, and disposal of food products", (Faurès et al., 2013). Figure 1 illustrated the six components of the food system, starting from raw materials supplies at the production stage; and the proposed $H T$ attributes. The raw materials will then go through the processing stage to produce the final food product before being distributed and marketed to consumers for consumption. The last stage of the food system is the waste recovery from the whole process. The cycle is continuous provided there is an interaction between demand and supply in the food market. The $H T$ attributes will be described in more detail in Section 5.

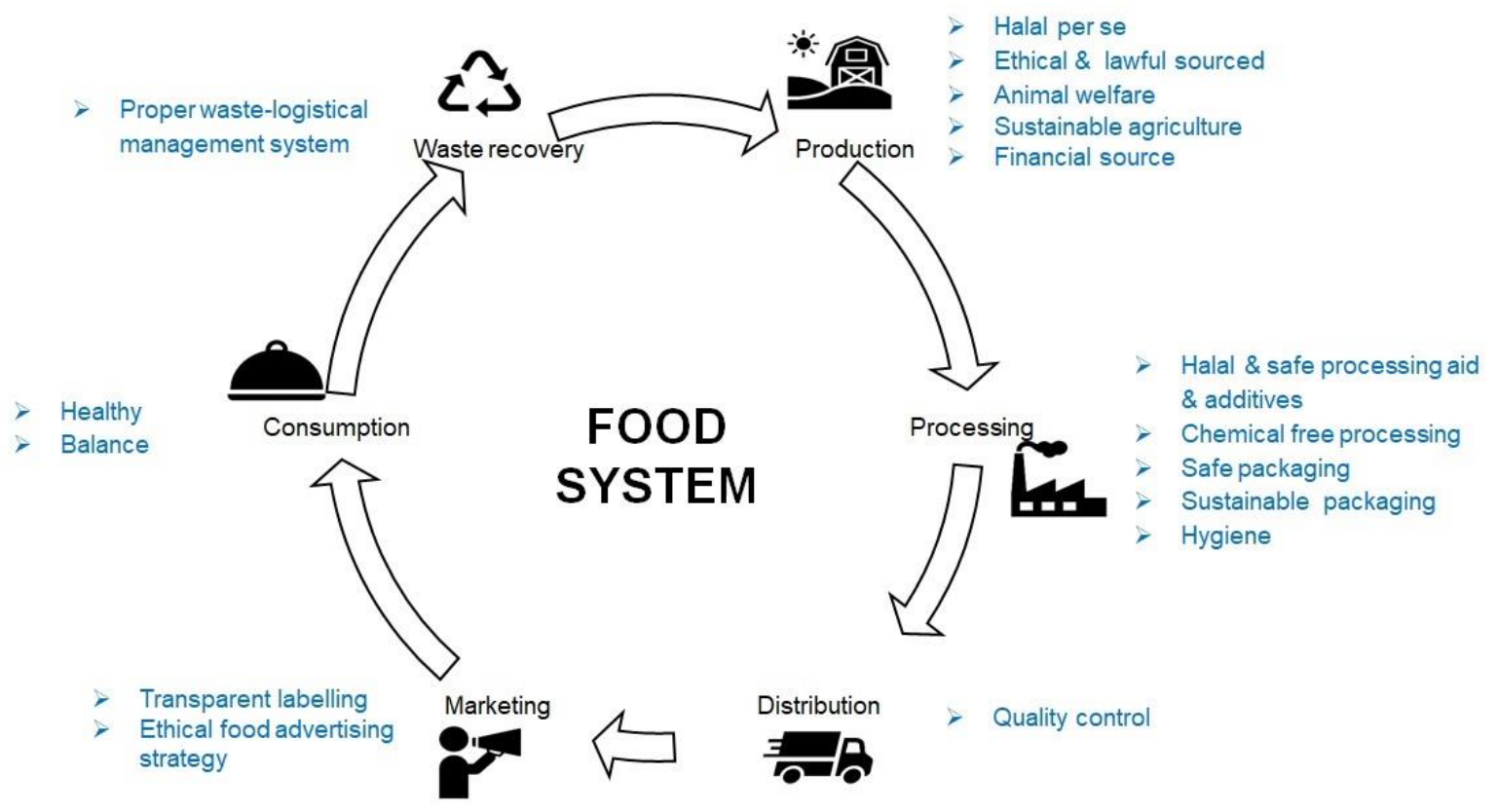

Figure 1. Six components of Food System (adapted from Eames-Sheavly et al., 2011) and the proposed Halalan Toyyiban (HT) attributes. 


\subsection{Literal meanings of Halal and Toyyib}

Halal (حلال) is an Arabic word that root from hillun (حِلُّ), translated as lawful, legal, licit, and legitimate. Other terms that share the same meaning are mubah sُبَاح (permissible, permitted, allowable, and allowed), and jaiz جَائز (permissible, permitted, and allowed). In terms of halal food, the frequent interpretation used for halal is 'permissible', (Alzeer, Rieder \& Hadeed, 2017; Liow, 2016; Zakaria, 2008). Meanwhile, Abdul Majid et al. (2015), added 'legitimate' as an additional literal interpretation for halal.

Another term that often simultaneously mentioned along with halal is toyyib (طَّبَ). This Arabic word is translated as good, pleasant, and agreeable. The synonyms for the word toyyib are jayyid حَبِّ (good, perfect, fine, well) and hasan (handsome, beautiful, graceful). Zakaria (2008), uses 'good quality' to refer to toyyib in his article. In some articles, the authors refer to toyyib as pure and safe (or hygienic), traits that are relevant to the food industry, (Alzeer et al., 2017; Dahlal \& Ahmad, 2018). According to Liow (2016), toyyib is wholesome, which also includes the element of nutrition. The following Qur'anic verse mentioned both halal and toyyib from the food perspective:

"O ye people! Eat of what is on earth, Lawful and good; and do not follow the footsteps of the evil one, for he is to you an avowed enemy." (Al-Baqarah, 2:168)

In this verse, Allah has commanded man to eat not only foods that are halal (lawful), but also food that are toyyib. Although the terms $H T$ are commonly associated with food products or consumption, in Islam, the applications of these terms affect all aspects of Muslim life, (Abdul Majid et al., 2015). For example, the Qur'an links the word of halal and haram with the marital affair in An-Nur verse 26, logistic in Yunus verse 22, financial management in al-Baqarah verse 267, (Deuraseh, 2019) and business conduct in al-Baqarah verse 227 (2:227). Nonetheless, this article only focuses on halal and toyyib in the food context.

\subsection{Halalan Toyyiban Attributes from Various Perspectives}

Several articles have attempted to elaborate on the concept of $H T$ from various perspectives. Alzeer et al. (2017), took a subject-process approach in rationalizing the relationship between halal and toyyib. The author argues that halal needs to be seen through the lens of the subject (e.g. raw material) while toyyib should be seen through the lens of process. A subject needs to go through a process to achieve the complementary objectives: to produce clean (maximum hygiene) and pure (minimum contaminations) foods and create a comfortable feeling when consuming it.

Meanwhile, several other authors have attempted to conceptualize $H T$ in a food context based on what has been described by mufasir (Qur'anic scholars). In his study, Wan Harun (2016), conducted a document analysis of 20 selected classical Qur'anic commentary (tafsir). These tafsir were selected after considering the reputation of the authors and the clear descriptions of halal and toyyib in the tafsir. Wan Harun (2016), discovered six principles of $H T$ which are (1) halal (2) acceptable by human nature; (3) hygienic, (4) nutritious; (5) safe (6) free from syubhah (doubtful things). In another study, which is also based on content analysis of selected tafsir, Mohamad and Wan Khairuldin (2018), listed four criteria of $H T$; these are (1) beneficial to humans; (2) valid sources (3) contain no prohibited things and (4) harmless to body and soul. There seemed to be a slight difference in emphasis of $H T$ by different authors studied in this work. For instance, $A l$ - 
Qurthubi describes $H T$ by emphasizing the need for food to be in good condition from the start, until the end of the food production. Meanwhile, Tafsir Al-Aisar emphasizes the safety and health implications.

Another way to look at HT concept is through the Tasawwuf lens. Tasawwuf is an Arabic term for "the process of realizing ethical and spiritual ideals", (Encyclopedia of Islam and the Muslim World, n.d). The proponents of the Tasawwuf perspective argue that $H T$ must not be confined solely to Fiqh (Islamic jurisprudence) approach, (Sungit et al., 2020). They instead emphasize physical and spiritual cleanliness and purity. This perspective gave rise to the movement and development of a management system, called Islamic Manufacturing Practice (IMP). IMP offers value-added manufacturing guidelines where all actions must be associated with a specific ritual (ibadah). Examples of the requirements in IMP include Muslim workers only policy, Syari'ahbased modest attires, and sharing sessions on religious knowledge. Sungit et al. (2020), however argued that while the IMP guidelines could potentially be developed further, certain requirements (e.g., Muslim workers only policy, no menstruating women in the production) imposed by the IMP may not be realistic in the manufacturing context, nor it is well-founded based on Syari'ah ground. Sungit et al. (2020), also argue that most scholars agreed that in conceptualizing $H T$ principles, formative rules of matters (zatihi) need to be used with the guidance of texts and benefit-harm (maslahah-mafsadah) outlook.

\subsection{Framing the Halalan Toyyiban Attributes from the Food System Perspective}

While there are efforts to describe the HT concept in food (section 4), this article is the first to analyse and highlight the attributes of $H T$ from the perspective of a current and modern food system approach. The attributes are described in more detail in the subsequent sections based on the food system components (production, processing, distribution, consumption, marketing and waste recovery).

\subsubsection{Production}

The production component highlights the source of food production which can be categorized into (1) raw material source that comes from the primary economic sector which is agriculture (crops and livestock) and (2) financial source that is used to fund the operation of the production. Under the production component (or dimension), the discussion breaks down into several attributes (sub-dimensions), namely halal per se, ethical and lawful source, animal welfare, sustainable agriculture and halal financial source, which are discussed in Table 1. Referring to the category above, the first four attributes fall under the raw materials category while the last attribute is under the finance category.

One of the Islamic legal maxims "nature is permissible until it is specifically prohibited", (Al-Qaradawi, 2007), implies that generally, all edible foods are permissible. Since the general ruling of foods allowed for consumption is broad, it is easier to filter them by excluding the haram per se animals or its derivatives from the raw materials permitted to be used in the production. 
Table 1: Halalan Toyyiban (HT) attributes in production component of the food system.

\begin{tabular}{|c|c|c|c|}
\hline $\begin{array}{l}\text { Component } \\
\text { (Dimension) }\end{array}$ & $\begin{array}{c}\text { Attributes } \\
\text { (Sub- } \\
\text { dimension) }\end{array}$ & Detail & Reference \\
\hline \multirow[t]{5}{*}{ Production } & Halal per se & $\begin{array}{l}\text { - HT principles highlight the list } \\
\text { of prohibited animals and haram } \\
\text { elements (including najs) that must } \\
\text { be absent from production of food, } \\
\text { such as carcasses, flowing blood, } \\
\text { swine flesh and its by-products, } \\
\text { unlawfully slaughtered animals, all } \\
\text { fanged beasts of prey, and all birds } \\
\text { having talons. }\end{array}$ & $\begin{array}{l}\text { Trade Descriptions } \\
\text { (Definition of halal) } \\
\text { Order } 2011 \\
\text { Department of } \\
\text { Islamic } \\
\text { Development } \\
\text { Malaysia (JAKIM) } \\
\text { (2014) } \\
\text { Department of } \\
\text { Standard Malaysia } \\
\text { (2019a) } \\
\text { Deuraseh (2019) } \\
\text { Muhammad } \\
\text { Mushfique (2018) }\end{array}$ \\
\hline & $\begin{array}{l}\text { Ethical and } \\
\text { lawful } \\
\text { sourced }\end{array}$ & $\begin{array}{l}\text { - HT principles elevate the } \\
\text { importance of ethical and legal } \\
\text { sourcing of materials by } \\
\text { condemning any act of theft, } \\
\text { stealing, or oppression from others. }\end{array}$ & $\begin{array}{l}\text { Mohamad \& Wan } \\
\text { Khairuldin (2018) }\end{array}$ \\
\hline & $\begin{array}{l}\text { Animal } \\
\text { welfare }\end{array}$ & $\begin{array}{l}\text { - } H T \text { principles support healthy, } \\
\text { comfortable, well-nourished, and } \\
\text { safe conditions for animals raised } \\
\text { as livestock. } \\
\text { - } H T \text { concept emphasizes the } \\
\text { origin of animal feed } H T \text { stressed } \\
\text { the importance of being } \\
\text { benevolence and compassionate } \\
\text { toward animals during pre- } \\
\text { slaughter and slaughter. }\end{array}$ & $\begin{array}{l}\text { Feed Act } 2009 \\
\text { Animal Welfare Act } \\
2015 \\
\text { Ali \& Suleiman } \\
\text { (2016) } \\
\text { Abd Kadir et al. } \\
(2016) \\
\text { Sira (2017) }\end{array}$ \\
\hline & $\begin{array}{l}\text { Sustainable } \\
\text { Agriculture }\end{array}$ & $\begin{array}{l}\text { - HT principles suggest an } \\
\text { application of innovative green } \\
\text { technologies to support the } \\
\text { agricultural sector in achieving } \\
\text { food security as suggested by } \\
\text { Sustainable Development Goals } \\
\text { (SDGs). }\end{array}$ & $\begin{array}{l}\text { Azemi }(2020, \\
\text { January 28) } \\
\text { United Nations } \\
\text { General Assembly } \\
(2015)\end{array}$ \\
\hline & $\begin{array}{l}\text { Halal } \\
\text { financial } \\
\text { source }\end{array}$ & $\begin{array}{l}\text { - HT principles require the halal } \\
\text { industry to be financially supported } \\
\text { by Islamic Finance instruments or } \\
\text { institutions that are free from } \\
\text { interest-based loans. }\end{array}$ & $\begin{array}{l}\text { Awang et al. (2016) } \\
\text { Abdullah and Oseni } \\
\text { (2017) } \\
\text { Islamic Finance } \\
\text { (2014) }\end{array}$ \\
\hline
\end{tabular}


Under the production component, emphasis is given on the halal status of raw material while very little attention is given to the financial source. This latter aspect has thus far been overlooked or neglected; as such, there is very limited literature in the field. Nevertheless, there are parties, including the industry practitioners, who support and advocate that halal financial sources should be one integral part of the food system.

For instance, the halal industry expert and managing director of Nur Global Strategies, Kavilash Chawla, once quoted, "trying to provide halal certified products without financing them through Islamic facilities demonstrates a fundamental disconnect from a belief perspective", (Finance, 2018). Islamic principles are holistic, but focusing on one aspect of the principles while ignoring other aspects is not acceptable. In this context, the food industry must ensure that halal compliance is applied in each stage of the value chain, including in the attainment of funding or financing, (Abdullah \& Oseni, 2017). Daud Vicary Abdullah, the first managing director of Hong Leong Islamic Bank, also supported this idea through his statement, "to ensure that the whole production process is halal, the source of financing should also be from a halal source, i.e., by using Islamic banking services", (Daud Awang et al., 2020). The halal industry's integration and inclusivity and Islamic finance are vital to be discussed, aiming for a more holistic halal standard, Awang et al., 2016).

\subsubsection{Processing}

Food processing is the transformation of agricultural products into food, or of one form of food into other forms. Food processing includes many forms of processing foods, from grinding grain to make raw flour to home cooking to complex industrial methods used to make convenience foods. In mass production, the processing stage is where the raw materials are being processed inside a designated premise that has proper machinery, tools and equipment to transform into new food products with a higher value known as processed food or convenience food. Manufacturers tend to depend on food technology, such as processing aids and packaging technology during processing, to improve product shelf-life and sales, (Dahlal \& Ahmad, 2018). Under the processing component, the attributes include halal and safe processing aids and additives, including chemical-free processing, safe packaging, sustainable packaging, and hygiene from the spiritual and physical perspective (Table 2).

Table 2: Halalan Toyyiban (HT) attributes in the processing component of the food system.

\begin{tabular}{|c|c|c|c|}
\hline $\begin{array}{l}\text { Component } \\
\text { (Dimension) }\end{array}$ & $\begin{array}{c}\text { Attributes } \\
\text { (Sub- } \\
\text { dimension) }\end{array}$ & Detail & Reference \\
\hline Processing & $\begin{array}{l}\text { Halal and safe } \\
\text { processing aids } \\
\text { and additives }\end{array}$ & $\begin{array}{l}\text { - HT principles emphasize the } \\
\text { need to strive in improving the } \\
\text { quality of food processed products } \\
\text { while minimizing the risk for } \\
\text { foodborne illness through the help } \\
\text { of food processing aids and } \\
\text { additives (e.g., food colourings, } \\
\text { sweetener, preservative, }\end{array}$ & $\begin{array}{l}\text { Department of } \\
\text { Islamic } \\
\text { Development } \\
\text { Malaysia (JAKIM) } \\
\text { (2014) } \\
\text { Department of } \\
\text { Standards Malaysia } \\
\text { (2019) }\end{array}$ \\
\hline
\end{tabular}


antioxidant, emulsifier, sodium carbonate and flavour enhancer)

- The essence of HT principles is maintained where haram elements must be absent in the processing aids and additives.

- HT principles prevent excessive usage of permitted chemical food aids in processing to safeguard health in the long run.

Safe packaging - $H T$ principles support the use of safe packaging and labelling for direct contact with food that meets the halal, GMP and HACCP requirements. Materials made from any hazardous materials shall be avoided.
Dahlal \& Ahmad

(2018)

Janjarasskul \&

Suppakul (2018)

\section{Department of \\ Islamic \\ Development \\ Malaysia (JAKIM) \\ (2014)}

Department of

Standards Malaysia

(2014)

Janjarasskul \&

Suppakul (2018)

\begin{tabular}{|c|c|c|}
\hline $\begin{array}{l}\text { Sustainable } \\
\text { packaging }\end{array}$ & $\begin{array}{l}\text {-HT principles require the } \\
\text { designation and development of } \\
\text { packaging to meet the halal and } \\
\text { GMP requirements while } \\
\text { observing the other aspects, } \\
\text { including the economic, social and } \\
\text { environment. }\end{array}$ & $\begin{array}{l}\text { Department of } \\
\text { Standards Malaysia } \\
(2014) \\
\text { Sonneveld et al. } \\
(2005)\end{array}$ \\
\hline $\begin{array}{l}\text { Hygiene: } \\
\text { physical and } \\
\text { spiritual }\end{array}$ & $\begin{array}{l}\text {-HT principles demand strict } \\
\text { observation on the cleanliness } \\
\text { aspect throughout the supply } \\
\text { chain, including the condition of } \\
\text { premises, workers appearance, } \\
\text { appliances and equipment for } \\
\text { processing. } \\
\text { The production area also shall } \\
\text { not contain any tools and elements } \\
\text { of religious worship to avoid any } \\
\text { doubt on the halal status. }\end{array}$ & $\begin{array}{l}\text { Department of } \\
\text { Islamic } \\
\text { Development } \\
\text { Malaysia (JAKIM) } \\
\text { (2014) } \\
\text { Food Hygiene } \\
\text { Regulations (2009) }\end{array}$ \\
\hline
\end{tabular}

Sungit et al. (2020) 
Food processing aids can be used in the process if it contains no Haram (and syubhah) and hazardous elements, (Janjarasskul \& Suppakul, Dahlal \& Ahmad, 2018). However, the Halal Standard discourages the use of excessive processing aids and additives due to potential health detrimental effects. This calls for proper re-examination on the application of processing aids and additives towards alternative chemical-free processes, (Dahlal \&Ahmad, 2018).

Packaging is another important attribute in the processing component of the food system. It can be further divided into two aspects; safe and sustainable packaging. Safe packaging commonly refers to the materials used in the packaging and their effect on consumers' safety and health, (Talib \& Johan, 2012). Although non-mainstream, innovative packaging technology such as active packaging and intelligent packaging is believed to be safer and could further reduce the chemical used in the production, (Janjarasskul \& Suppakul, 2018); and thus, warrant further investigation to benefit the Halal food system.

Meanwhile, sustainable packaging is characterized as packaging that can be continuously recycled and imposes no environmental risk, which adds value to society, (Sonneveld et al., 2005). Adopting sustainable packaging is a complex topic as there is economic and social consideration that is linked with environmental impact, (Sonneveld et al., 2005). While packaging needs redevelopment by integrating sustainable elements, the commercial performance (marketable) and functionality of packaging (protection, utility, and communication) must be retained, (Sonneveld et al., 2005, Grundey, 2010).

Another attribute in the processing component; hygiene and cleanliness, has been included in the Halal standards and Manual Procedure for Malaysia Halal Certification. However, it covers mostly the physical appearance of workers and premises that can be easily observed and audited. To achieve wholesomeness, it is timely and important that cleanliness and purity should also be given attention from the spiritual perspective. This aspect must not be a constraint to the ritual obligation (e.g., prayers) which is impractical for non-Muslim producers. One possible integration is incorporating MS 1900 (Shariah-Based Quality Management System) into certification requirements. MS 1900 ensures universally accepted values and practices (grounded in Islamic laws) are integrated into the management process of the halal companies.

\subsubsection{Distribution}

The distribution component in the food system is the connector between the production point with the consumer point, (Tieman, 2011; Zailani et al., 2018). It consists of transporting and storing activities. It has been recognized as an integral part of the logistic process and is crucial to ensure Halal products' purity, (Zailani et al., 2018). This component consists of quality control during transportation and storage that would ensure the delivery of products that satisfy customer needs (Table 3 ).

Table 3: Halalan Toyyiban (HT) attributes in distribution component of the food system.

\begin{tabular}{lllll}
\hline $\begin{array}{l}\text { Component } \\
\text { (Dimension) }\end{array}$ & $\begin{array}{c}\text { Attributes } \\
\text { (Sub- } \\
\text { dimension) }\end{array}$ & \multicolumn{1}{c}{ Detail } & Reference \\
\hline Distribution & $\begin{array}{l}\text { Quality } \\
\text { control during }\end{array}$ & $\begin{array}{l}\text { - } H T \text { principles support the efforts } \\
\text { to improve the quality control of } \\
\text { products during the logistic stage by }\end{array}$ & $\begin{array}{l}\text { Department of } \\
\text { Standards }\end{array}$ \\
\hline
\end{tabular}




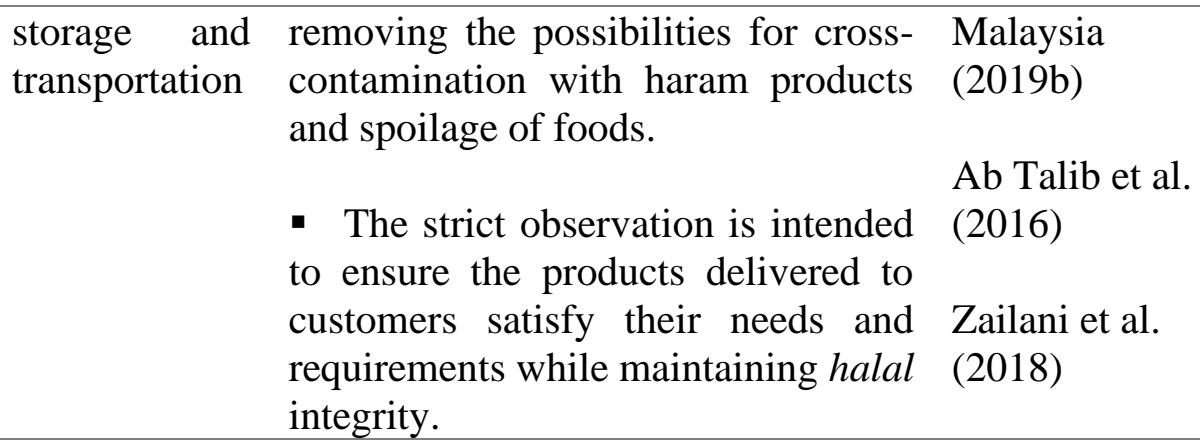

$\mathrm{Ab}$ Talib et al.

- The strict observation is intended (2016)

to ensure the products delivered to customers satisfy their needs and Zailani et al. requirements while maintaining halal (2018) integrity.

Halal logistics has thus far improved the accessibility of halal products to consumers. However, as in any logistic field, there is a concern about waste and carbon footprint generated from logistic activities, (Tieman et al., 2012). Besides, Tieman et al. (2012), also pointed out the difference between halal logistic with the conventional model is that the halal logistic takes into consideration human values, ethics and sustainability. This has put greater pressure on the halal industry to properly execute the distribution operation and activities while safeguarding these aspects.

\subsubsection{Marketing}

Marketing is a way for a company to break through the market to stay competitive. Marketing plays no less importance in the halal food industry since its function is to plan the direction of production based on observation and research on the desired market. Proper marketing is very important to maintain the reputation of the halal brand, (Talib \& Johan, 2012). As shown in Table 4, the marketing component in the food system consists of (1) ethical food advertising strategy and (2) transparent labelling.

Table 4: Halalan Toyyiban (HT) attributes in marketing component of the food system.

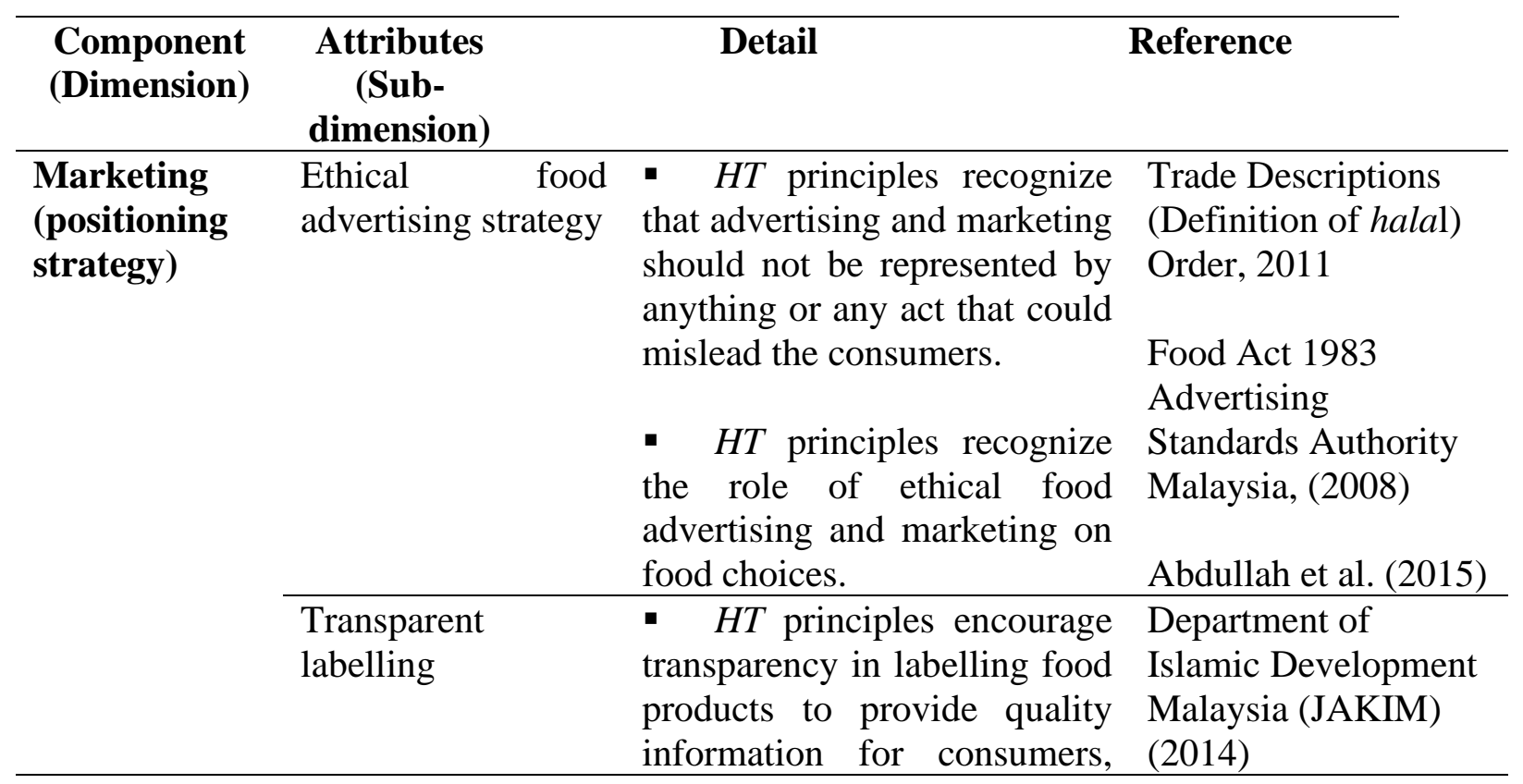




avoid the possibility of fraud
and false claims from
$\begin{aligned} & \text { Standards Malaysia } \\ & \text { producers. }\end{aligned}$

Abdullah et al. (2015)

The first attribute, ethical food advertising strategy could be achieved through the practice of Islamic marketing. While adhering to the marketing framework of the mixed model, Islamic marketing has the inclusion of Islamic values and principles to make it Syari'ah-compliant as required for the halal market, (Ishak \& Abdullah, 2012; Munib et al., 2017). The foundation of the marketing mix consists of four elements known as 4Ps; (1) Product; (2) Promotion; (3) Price; and (4) Place. Ishak and Abdullah (2012), has also included (5) Person, in this list. Munib et al. (2017). have suggested several characteristics of Islamic marketing that are realistic, humanistic, and transparent. In another paper, Abdullah and Oseni (2017), suggested that spiritualistic, ethical, realistic and humanistic are part of Islamic marketing characteristics. In addition to that, Shafiq et al. (2017), have specified several relevant rules for Islamic advertising such that: "(1) it should not exploit basic instincts of consumers and should avoid provoking desires that can never be fulfilled; (2) it should be based on truth and complete revealing of all product attributes; (3) the product should not be haram neither should it be harmful; and (4) it should advocate consumption as a form of worship and promote moderation in the same."

Transparent labelling is another attribute in the marketing component of the food system. In Malaysia, food labelling and design guidelines are governed by Food Regulations, namely Malaysian Food Regulations 1983 and Food Irradiation Regulations 2011, (Loong, 2013). Labels are an important marketing tool that contains the necessary information as well as representing the commitment promised by the manufacturers. For example, the halal logo that is being displayed on food packaging will inform that the product is produced with permitted ingredients through proper processes that comply with Syari'ah. Meanwhile, labels for halal products must include the complete list of the ingredients used with no intentional exclusion. This is in contrast with the current established labelling practice where certain types of ingredients can be omitted from the labels. This could mislead and discriminate against customer's rights to know and make informed choices. Shafiq et al. (2017), strongly opposed the practices of omitting, fabricating, and providing false information in labelling; and this shall be regarded as fraud or deception. Transparent labelling must reflect the true information given as well as the quality of the product.

Another interesting aspect to take into consideration is the quality of the personnel undertaking the marketing role of a product. Abdullah et al. (2012), argued that the attitudes of personnel dealing with business conduct can influence the perception of consumers toward one's product or brand. Proper marketing is very important to maintain the reputation of the halal brand, (Talib \& Johan, 2012).

\subsubsection{Consumption}

Consumption in the food system is the stage where the consumers or the final users select or decide on the food products, including the ways of preparation, processing, and cooking. The term consumption is also closely associated with diet or food intake. In general, $H T$ food must be beneficial with no element that could harm the human, spiritually, and physically. Three main 
attributes that are associated with the consumption stage are (1) food safety and quality (2) healthy and nutritious, and (3) balance (Table 5).

Table 5: Halalan Toyyiban (HT) attributes in consumption component of the food system.

\begin{tabular}{|c|c|c|c|}
\hline $\begin{array}{l}\text { Component } \\
\text { (Dimension) }\end{array}$ & $\begin{array}{l}\text { Attributes } \\
\text { (Sub- } \\
\text { dimension) }\end{array}$ & Detail & Reference \\
\hline \multirow[t]{5}{*}{ Consumption } & Food safety & $\begin{array}{l}\text { - Preparation, processing, and } \\
\text { cooking in a hygienic way } \\
\text { - } H T \text { principles demand that food } \\
\text { not contain injurious, hazardous or } \\
\text { poisonous substances to health with } \\
\text { limited food additives usage. }\end{array}$ & $\begin{array}{l}\text { Department of } \\
\text { Standards } \\
\text { Malaysia (2019) }\end{array}$ \\
\hline & $\begin{array}{l}\text { Healthy and } \\
\text { nutritious }\end{array}$ & $\begin{array}{l}\text { - Any extraction } \\
\text { substance/ingredient must not } \\
\text { diminish the nutritive or other } \\
\text { beneficial properties of food. }\end{array}$ & $\begin{array}{l}\text { Mohamad \& Wan } \\
\text { Khairuldin (2018) } \\
\text { Arif \& Sidek } \\
(2015)\end{array}$ \\
\hline & Balanced & $\begin{array}{l}\text { - HT principles promote } \\
\text { energy/calorie consumption } \\
\text { limitation and reduce portion size to } \\
\text { prevent overweight, obesity, and } \\
\text { diet-related non-communicable } \\
\text { diseases. }\end{array}$ & $\begin{array}{l}\text { National } \\
\text { Coordinating } \\
\text { Committee on } \\
\text { Food and } \\
\text { Nutrition (2013) }\end{array}$ \\
\hline & & & $\begin{array}{l}\text { Mohamad \& Wan } \\
\text { Khairuldin (2018) }\end{array}$ \\
\hline & & & $\begin{array}{l}\text { Salmon, Fennis, } \\
\text { De Ridder, } \\
\text { Adriaanse \& De } \\
\text { Vet (2014) } \\
\text { (Mohamad \& } \\
\text { Khairuldin, 2018) } \\
\text { (Mohamad \& } \\
\text { Khairuldin, 2018) }\end{array}$ \\
\hline
\end{tabular}

Food safety perhaps is the most frequent $H T$ attributes mentioned in the previous literature, (Kohilavani et al., 2013; Neio Demirci, Soon, \& Wallace 2016). Unsafe food, in general, may contain bacteria, viruses, parasites, toxins, metal, or harmful chemical substances. It is associated with more than 200 diseases, including severe diarrhoea, meningitis, and gastrointestinal infections. Contamination from chemical substances for instance can lead to acute poisoning or long-term diseases, such as cancer. An estimated 600 million individuals worldwide become ill due to the consumption of unsafe food, which is about one in 10 people worldwide. Verse 2:195 of the Qur'an indicates the instruction for people to stay away from any destruction, including harm from unsafe food. The threat of unsafe food intake is also against the 
principle of toyyib. To ensure the safety of products, food, therefore, needs to be prepared or processed in hygienic and safe manners, commercially and domestically. However, compared to the manufacturing and foodservice context, (Kohilavani et al., 2013; Neio Demirci et al., 2016), there is a lack of study conducted in food safety practices as an attribute of Halalan Toyibban in the domestic environment.

Halal food needs to be safe and healthy and nutritious, (Hassan et al, 2015; Mohamad \& Wan Khairuldin, 2018). Consuming halal food is important to fulfil religious requirements and all at once attain a healthier lifestyle, (Alzeer, Rieder, \& Hadeed, 2017). While halal-certified food products are required to be safe, halal-certified products are not necessarily healthy or nutritious under the current halal requirements. Until these elements of toyyib are properly embodied in the halal certification, it is up to the consumers to choose the better option. As such, consumer empowerment and education are important. One of the tools to empower consumers is through food labelling, (Chowdhary, 2003).

In facilitating consumers to choose healthy and nutritious food, manufacturers and foodservice establishments are responsible to provide consumers with accurate information and labels (see section 5.4 for discussion). Halal food manufacturers are accountable to provide the nutrition label on packaging as required by Food Regulations 1985 and MS1500:2019. Information needed on the food packaging includes illustrations; logos; product details; the quantity of food; ingredients; nutrition facts; manufacturer/importer; and expiration date. Despite the readily available nutrition information, a study conducted by Cheah, Moy and Loh (2015), revealed that only 11-15 percent of Malaysian adults' $(n=39,506$ participants) read the nutrition labels. To assist Malaysian consumers in making informed and healthier food choices Healthier Choices Logo (HCL) was introduced by the Ministry of Health in April 2017. With the HCL logo, consumers could choose healthier options only by looking at the logo on the packages, (Ministry of Health Malaysia, 2020).

To achieve a healthy lifestyle, healthy and nutritious foods need to be consumed in the right portion, moderately, (Salmon et al., 2014). One of the Islamic values that fit into this attribute is wasatiyyah (moderation). Consuming food beyond moderation can also harm one's life (Mohamad \& Wan Khairuldin, 2018), which goes against the toyyib concept. The Qur'an has stipulated the importance of moderate serving and portion size in the following verse.

"Eat and drink, but avoid excess" (Ta-ha, 20:81)

$H T$ principles promote the limitation of calorie consumption and reduce portion sizes to prevent overweight, obesity and diet-related non-communicable diseases. The maintenance of health and well-being is in line with maqasid al-syari'ah (objective of Islamic law), to preserve and protect values of religion (as a way of life), life and the intellect, (Hashim \& Ahmad, 2020). Although Islam has always advocated a healthy diet to maintain a good state of health and wellbeing, the prevalence of obesity and many other diet-related diseases in many Muslim countries shows that the toyyib element of consumption is not integrated into the life of individual Muslim and the community at large, (Hashim, Ahmad, \& Mohd Salleh, 2020).

The consumption component, especially related to the healthy, nutritious, balanced food intake is pertinent but not highlighted enough in the literature. There is a disproportionate emphasis on the halal aspect (e.g., permissibility of source and processing) compared to the toyyib aspect the healthy, nutritious, and balanced food intake. There is an urgent need to further re-educate Muslim society on an integral part of healthy, nutritious, and balanced attributes in $H T$ 
consumption. Especially now with the increasing challenges of rapid urbanization and increased variety and availability of ultra-processed foods that have changed the pattern of diet, regrettably towards unhealthy food consumption.

\subsubsection{Waste Recovery}

The generation of food waste throughout the food system is estimated to be one-third of food produced and has a large share of waste generated around the world that has become a serious concern, (HLPE, 2014; Ravindran \& Jaiswal, 2016). The inclusion of waste recovery as part of the food system shows a positive development towards the sustainability of the system. Table 6 shows the proper waste-logical management system planning as an attribute of the waste recovery component of the food system.

Table 6: Halalan Toyyiban (HT) attributes in waste recovery component of the food system.

\begin{tabular}{|c|c|c|c|}
\hline $\begin{array}{l}\text { Component } \\
\text { (Dimension) }\end{array}$ & $\begin{array}{l}\text { Attributes } \\
\text { (Sub- } \\
\text { dimension) }\end{array}$ & Detail & Reference \\
\hline $\begin{array}{l}\text { Waste } \\
\text { recovery }\end{array}$ & $\begin{array}{l}\text { Proper waste- } \\
\text { logistical } \\
\text { management } \\
\text { system planning }\end{array}$ & $\begin{array}{l}\text { - } H T \text { concept recognizes the } \\
\text { importance of efficient and } \\
\text { effective waste management } \\
\text { aiming to lessen waste } \\
\text { generation at the source level. } \\
\text { - HT principles are required } \\
\text { for managing the waste } \\
\text { effectively by properly } \\
\text { separating the carcasses of } \\
\text { animals that died not due to } \\
\text { proper slaughter to avoid them } \\
\text { being sold together with halal } \\
\text { meats. }\end{array}$ & $\begin{array}{l}\text { Department of } \\
\text { Islamic } \\
\text { Development } \\
\text { Malaysia (JAKIM) } \\
\text { (2014) } \\
\text { Department of } \\
\text { Standards Malaysia } \\
\text { (2019a) } \\
\text { Cristea (2016) } \\
\text { National Solid } \\
\text { Waste } \\
\text { Management } \\
\text { Department (2016) } \\
\text { Omar, Khan and } \\
\text { Hashi (2018) } \\
\text { Riza Ahmed \& } \\
\text { Monjur, (2010) }\end{array}$ \\
\hline
\end{tabular}

Proper waste management has been mentioned but not highlighted in detail in the halal guidelines. In halal standard (MS 1500:2019) for example, waste management is mentioned under sub-clause 4.4.2 "b) manage the waste effectively". The Malaysian Protocol for the Halal Meat and Poultry Production also briefly outlined the process for managing waste from slaughterhouse under the sub-clause 4.5.2 "l) animals that are dead due to stunning (if used) producer shall be identified as non-halal conformance, segregated and recorded". These sub-clauses indicate that current management for waste in Halal-certified establishments is more focused on the proper disposal method. 
According to Demirbas (2011), waste management consists of the collection, transport, sorting, recycling or disposal and control of waste materials. A traditional waste management system involves the collection, pre-treatment of transport, sorting and final disposal of waste. Waste management aims to provide sanitary living conditions to minimize the amount of matter entering or leaving society and facilitate the reuse of matter. The waste management system aims to ensure that waste materials are removed safely and properly from the source or location where they are produced and handled, disposed of, or recycled.

Minimizing waste is a top priority while recycling is the second priority. In terms of environmental impacts, waste management is classified into six levels, from low to high: reduction, reuse, recycling, composting, incineration and the landfill, (Siddique et al, 2008). The waste created represents the essence and scale of the operation of the company in most companies. Waste produced on-site that cannot be prevented should be properly processed and transferred for off-site disposal to adequately controlled waste contractors.

The waste recovery method is a less-mentioned aspect of waste management in the halal industry. Valorization is one of the promising food waste recovery technologies and techniques that convert food wastes into high-added-value products, (Ghosh et al., 2016). Another related technique is biorefinery that converts the biomass into value-added chemical products such as biogas, biohydrogen, and biofertilizer, (Sulaiman et al., 2014). If halal food manufacturers can properly utilize these new processes and techniques, the disposal of food wastage can be greatly reduced while contributing greatly to the economy, society, and environment, which is in line with the food system's goal.

\subsection{Challenges and Recommendations in Upholding Halalan Toyyiban as a Holistic Concept in the Food System}

Discussion in the previous sections has dissected the established food system cycle based on its components to identify the gaps of which $H T$ attributes are in absence, in the quest to arrive at the conceptual clarity of the term itself. Beyond the conceptual clarity, $H T$ attributes can be an ideal vehicle to provide safe, high quality, good and wholesome food; in an ethical and sustainable ecosystem. Despite the positive development of the halal market, industry, and ecosystem, there are challenges for the public, manufacturers, and regulators to overcome in upholding and practicing $H T$ holistically.

Future research and studies are warranted to provide empirical evidence of the benefits of the $H T$ holistic concept in the food system. This shall help increase awareness among the public (consumers) and manufacturers. Such data shall also be useful to direct halal policymakers to reexamine halal standards to include $H T$ elements in the halal food industry towards a holistic system.

\subsubsection{Consumer Side}

The public is aware of the halal status of a product, but forgetting or ignoring the toyyib part, which is an integral part of halal principles, (Abdul Majid et al., 2015; Liow, 2016). This notion is supported by Zainol et al. (2020), who found that consumers tend to make purchases of products based on the halal logo rather than the nutrition label. While it is encouraging that the public refers to the halal logo in making their purchase decision, they are less concerned about other elements of the food, for instance, the high content of sugar or salt. The latter does not meet 
the toyyib criteria of which can cause deleterious health effects. To this end, toyyib that promotes the nutritious and balance aspect in dietary practice seems to be less recognized as part of halal food by the public. The detachment of toyyib's perspective thus poses a real challenge to achieve a healthy lifestyle.

Meanwhile, another group of consumers with higher awareness of halal and a healthy eating lifestyle cannot choose a healthier choice of food due to several factors; one of them is the price of the product, (Zainol et al., 2020). In extension to this discussion, a study done by Abrams et al. (2015), revealed that several factors hinder parents from making healthy food choices for their children. This includes time-constraint for purchasing, parents' objectives, and Front-ofPackage Visual. The first two factors indicate that parents are not ignorant of their children's health. They are aware of the importance of having nutritious foods but are unable to exclude unhealthy foods (snacks or junk foods) from their final food choices due to other external factors. While knowledge and awareness from the consumer side could contribute to the adherence to $H T$ food choices, other attributes in the whole food system also need adjustment to achieve the holistic aim.

In the quest to create awareness of the holistic $H T$ concept and practice, the rapid spread of information through technology can be utilized in addition to more conventional campaigns. The right knowledge on halal standards and related matters may increase public sensitivity towards $H T$ issues. This then shall create more inclusive public participation as 'halal watcher' where the public take responsibility to report any doubtful status of products or manufacturer to the authority for further inspection, (Abd Rahim, 2020).

Exposure to the $H T$ concept through proper education from an early age of preschool level right into the school curriculum is also a good strategy to improve knowledge and awareness towards the desired behavioural change. For instance, Halalan Toyibban can be taught through halal science modules that incorporate lessons on a balance diet, (Awang et al., 2014; Zainol et al., 2020). The module used needs to emphasize the benefits of a healthier diet and lifestyle rather than just informing them what is balance diet. Parenting modules or programs aimed at expectant parents could also be a good platform to educate about a healthy diet in which the knowledge can be applied in their future children and family.

\subsubsection{Manufacturers and Producer Side}

Manufacturers play a crucial role to make it possible for $H T$ to be practiced hence producing food products and services that truly meet the Halalan Toyibban elements for consumption. Despite the increase of players in the halal food industry, it seems that the most challenging aspect for a producer is to maintain the halal principles without neglecting the profit. Commonly, the objective of a company or producer is to maximize the profit and minimize the cost. Due to this mindset and goal, some believe that HT is relatively harder to implement as the principles demand more critical and specific operational and management practices in the supply chain, (Arif \& Sidek, 2015) that could incur additional cost. Relatively, it may become a burden for halal operators that at present, most are from small-medium enterprises with known financial constraints.

Another challenge for the producer to uphold $H T$ in the food system is the lack of traceability in processing and manufacturing. Inability to trace contamination of haram elements that may occur at any stage of production can become a threat to food safety; which is an inherent 
aim of the HT concept to produce food free from chemical substances, high quality and nutritious by proper handling and processing, and storage of products.

Ignorant manufacturers can be educated through courses or programs offered by authorities and related agencies. In Malaysia, these entities could be Jabatan Kemajuan Islam Malaysia (JAKIM) or Halal Development Corporation (HDC). The manufacturers and producers should put in efforts to participate in halal exhibitions, seminars, or conferences that expose them to current issues in the halal industry. This will help them to keep updated on trending halal issues so that they can adjust accordingly. On the other hand, the government should provide incentives to attract non-halal-certified manufacturers to consider halal certification for their products. This shall ease the monitoring of processed foods products circulating in the market. Eventually, it can lessen the risk of doubtful food products being consumed by Muslim consumers. Liow (2016), mentioned the need to rebrand and reintroduce the knowledge on halal as it is not limited to religious scope but applies to the whole of humanity. Abdullah and Oseni (2017), have revealed the positive intention for practicing Islamic financial planning among the halal operators about the financial issue.

\subsubsection{Policy and Governance}

To date, consumers in Malaysia have been protected by several related Halal Standards, Acts and Regulations which include Trade Descriptions Act 1972, Trade Descriptions (Use of Halal Expression) Order 1975, Trade Descriptions (Marking of Food) Order 1975, Consumer Protection Act 1999, Food Act 1983, Food Regulation 1985, Animal Rules 1962, MS 1500:2019, MS 1480 and MS 1514.

However, it is observed that the imposition of these acts, regulations and standards have not been entirely successful in influencing the intention to practice $H T$ in the components of the food system. In the case of Malaysia, the requirement for halal certification and the use of the halal logo is voluntary. This may affect the attitudes of manufacturers toward halal products and services. Since it is voluntary, it becomes challenging to motivate manufacturers to halal-certify their products. Some of them argue that it is unnecessary to apply for halal certification so long that they can persuade potential buyers that their product is indeed 'halal', (Che Omar, 2020; Zakaria, 2008). It is especially difficult to promote the spirit of HT since Muslim manufacturers tend to disregard the importance of halal certification and tend to associate 'halal status' with 'being Muslim'. Muslim manufacturers' unwillingness to comply with these standards is due to issues of cost and complexity of documentation and processes. They fail to see benefits beyond the obstacles. On the other hand, non-Muslim producers find it especially lucrative to get involved in the halal food industry, but they are challenged with insufficient ability to grasp the full spirit behind the HT concept. To this end, it becomes a concern that Malaysia's halal logo remains only as a tool to attract Muslim consumers, (Abdul Majid et al., 2015).

This brings us to the next point in the policy and governance aspect of the challenges to uphold $H T$ as a holistic concept in the food system. Some elements of toyyib have been included in certain aspects of halal certification, for instance in "item (v) of Trade Description Act 1972: Is not poisonous or deleterious to health". Toyyib elements are also found in the Malaysian Halal Standard MS 1500:2019, MS 1480, and MS 1514 that cover food handling, preparation, storage, safety, and hygiene, which indicates some degree of realization of the $H T$ concept in halal certification, (Dahlal \& Ahmad, 2018). However, the coverage is still very limited with loopholes that may hinder the holistic implementation of $H T$ concept. This may be due to the lack of 
conceptual clarity of the term $H T$ itself; and the mindset that halal and toyyib are different entities as opposed to its holistic form. It is noteworthy that the halal certification in Malaysia does not carry the term toyyib in its nomenclature.

Lack of governance in terms of financial sources in the halal industry also hinders the attainment of the wholesome aspect of HT. Although Islamic finance seems to be more mature and established, it seems to be disconnected from the halal industry for the latter to benefit from it. Abdullah and Oseni (2017), explained that the disconnection between halal financing with halal industry might be due to the exclusion of halal-certified finance operators from the conventional finance and investment landscape and that Islamic banking institutions are not focusing on the lending activities. The halal financial source is currently not part of the requirements to obtain a halal certificate (MS1500:2019). The lack of governance of financial sources in the HT pipeline has rendered the halal industry players to use their preferred financial instruments to fund their businesses through conventional financing that could involve elements of riba' (interest), (Abdullah \& Oseni, 2017). It is timely that Islamic finance reassesses its service and marketing to provide services for halal-related industrial activities.

\section{CONCLUSION}

Halal food has received tremendous attention from scientific and industrial communities as an important subject to be addressed and discussed. However, the more holistic concept of $H T$ is less known and practiced, mainly due to the lack of conceptual clarity of the term. This article suggests a holistic approach for $H T$ within the Food System perspective, manifesting multiple attributes of $H T$ from six components of the food system - production, distribution, processing, marketing, consumption, and waste recovery. An explicit conceptual clarity of HT shall create a ripple effect towards a change of mindset and behaviour of all stakeholders leading to the attainment of the wholesomeness of $H T$.

\section{DECLARATION OF INTEREST}

The authors declare no conflict of interest. This research did not receive any specific grant from funding agencies in the public, commercial or not for profit sectors.

\section{REFERENCES}

[1] Ab Talib, M. S., Abdul Hamid, A. B., \& Chin, T. A. (2016). Can halal certification influence logistics performance?. Journal of Islamic Marketing, 7(4), pp. 461-475. http://dx.doi.org/10.1108/JIMA-02-2015-0015

[2] Abd Kadir, M. H., Rasi, R. Z. R. M., Omar, S. S., \& Manap, Z. I. A. (2016, November). Halal Supply Chain Management Streamlined Practices: Issues and Challenges. In IOP Conference Series: Materials Science and Engineering 160(012070). https://doi.org/10.1088/1757-899x/160/1/012070

[3] Abd Rahim, M. J. (2020, May 12). Halal Watcher All Eyes and Ears for Halal (Google Meet). INHART E-seminar series 2/2020, 12 May 2020.

[4] Abdul Majid, M. A., Zainal Abidin, I. H., Mohd Abd Majid, H. A., \& Tamby Chik, C. (2015). Issues of Halal Food Implementation in Malaysia. Journal of Applied 
Environmental and Biological Sciences, 5, pp. 50-56.

[5] Abdullah, A. (2018). Difference between Halal and Halalan-Toyyiban. The New Straits Times. https://www.nst.com.my/opinion/columnists/2018/04/357046/difference-betweenhalal-and-halalan-toyyiban

[6] Abdullah, R.B., Ismail, N. B., Abdul Rahman, A. F. B., Mohd Suhaimin, M. B., Bte Safie, S. K., Mohd Tajuddin, M. T. H., Noor Armia, R., Nik Mat, N. A., Derani, N., Samsudin, M. M., Adli Zain, R., \& Sekharan Nair, G. K. (2012). The Relationship between Store Brand and Customer Loyalty in Retailing in Malaysia. Asian Social Science, 8(2). http://dx.doi.org/10.5539/ass.v8n2p171

[7] Abdullah, S., \& Oseni, U. A. (2017). Towards a sharī'ah compliant equity-based crowdfunding for the halal industry in Malaysia. International Journal of Business and Society, 18(1), pp. 223-240.

[8] Advertising Standards Authority Malaysia. (2008). The Malaysian Code of Advertising Practice (Third Edition). https://asa.org.my/files/ASA-code-eng.pdf

[9] Ahmad, S. J. (2019). Waste Management in a Halal Certified Establishment. Toyyiban Management Program in the Halal Assurance System. HASJ Consultancy. https://www.academia.edu/38441075/Waste_Management_Program_in_A_Halal_Certifi ed_Establishment

[10] Al-Qaradawi, Y. (2007). The Lawful and the Prohibited in Islam. Islamic Book Trust.

[11] Ali, M. H., \& Suleiman, N. (2016). Sustainable food production: Insights of Malaysian halal small and medium sized enterprises. International Journal of Production Economics, 181, pp. 303-314. https://doi.org/10.1016/j.ijpe.2016.06.003

[12] Alzeer, J., Rieder, U., \& Hadeed, K. A. (2017). Rational and practical aspects of Halal and Toyyib in the context of food safety. Trends in Food Science and Technology, 71(July), pp. 264-267. https://doi.org/10.1016/j.tifs.2017.10.020

[13] Arif, S., \& Sidek, S. (2015). Application of Halalan Toyyiban in the standard reference for determining Malaysian halal food. Asian Social Science, 11(17), pp. 116-129.

[14] Awan, H. M., Siddiquei, A. N., \& Haider, Z. (2015). Factors affecting Halal purchase intention - evidence from Pakistan's Halal food sector. Management Research Review, 38(6), pp. 640-660. https://doi.org/10.1108/MRR-01-2014-0022

[15] Awang, M. D., Mohd Noor, M. N. A., Muhammad, J., Abdullah, A., Ab. Rahman, S., \& Dato Yahya, M. H. (2016). Acceptance and Application of Islamic Financial Planning Among Small and Medium Enterprises Halal Operator in Peninsular of Malaysia. International E-Journal of Advances in Social Sciences, 2(6), pp. 747-752.

[16] Awang, M. D., Muhammad, J., Noor, M. N. A. M., Abdullah, A., Abdullah, A. A., Abdullah, N., \& Abai, D. S. A. (2020). Knowledge, Acceptance and Application of Islamic Financial Management among Small and Medium Enterprises (SMEs) Halal Entrepreneurs in Peninsular of Malaysia. In International Conference on Islam, Economy, and Halal Industry, KnE Social Sciences, pp. 216-226. https://doi.org/10.18502/kss.v4i9.7327.

[17] Awang, R., Rahim, R. A., Yusoff, K., Nasir, B. M., Ripin, M. N., Haron, Z., \& Ebrahimi, M. (2014). Halal Epistemology from a Global Perspective. Medwell Journals, 9(6), pp. 375-378. http://dx.doi.org/10.36478/sscience.2014.375.378

[18] Azemi M. Noor. (2020, January 28). Sustainable Halal Food Security. Islamic Organization for Food Security. https://iofs.org.kz/post/125

[19] Bellotti, W., Lestari, E., \& Fukofuka, K. (2018). A Food Systems Perspective on Food and Nutrition Security in Australia, Indonesia, and Vanuatu. In D. Barling, \& J. Fanzo (Eds.), 
Advances in food security and sustainability (pp. 1-51). Cambridge, MA USA: Academic Press. https://doi.org/10.1016/bs.af2s.2018.10.001

[20] Bonne, K., \& Verbeke, W. (2008). Religious values informing halal meat production and the control and delivery of halal credence quality. Agriculture and Human Values, 25, pp. 35-47.

[21] Charis. G. (2016, March 28). How Food Waste Recovery Improves Sustainability of Food Systems/ Scitechconnect. Elsevier. http://scitechconnect.elsevier.com/food-wasterecovery-sustainability-food-systems/

[22] Che Omar, K. (2020, September, 26). "Why Muslim entrepreneurs should obtain halal certification". The New Straits https://www.nst.com.my/opinion/columnists/2020/09/627309/why-muslim-

entrepreneurs-should-obtain-halal-certification\#: :text=as\%20an\%20ibadah.,In $\% 20$ essence $\% 2 \mathrm{C} \% 20$ as $\% 20$ Muslims $\% 2 \mathrm{C} \% 20$ we $\% 20$ need $\% 20$ to $\% 20$ support $\% 20$ the $\%$ 20halal,attention\%2C\%20especially\%20the\%20Muslim\%20buyers.

[23] Cheah, Y. K., Moy, F. M., \& Loh, D. A. (2015). Socio-demographic and lifestyle factors associated with nutrition label use among Malaysian adults. British Food Journal, 117(11), pp. 2777-2787. https://doi.org/10.1108/BFJ-01-2015-0001

[24] Chowdhary, U. (2003). Labels and hangtags: tool for consumer empowerment and education. International Journal of Consumer Studies, 27(3), p. 244. https://doi.org/10.1046/j.1470-6431.2003.00308_36.x

[25] Combs, G. F. (2000). Food system-based approaches to improving micronutrient nutrition: The case for selenium. BioFactors, 12(1-4), pp. 39-43. https://doi.org/10.1002/biof.5520120107

[26] Cristea, A. (2016). Food Waste Management Development Plan for Industry, Commercial and Institution Sector. Revista Brasileira de Ergonomia, pp. 1-10.

[27] Dahlal, N. M., \& Ahmad, F. A. (2018). Beyond Halal in Food Product: Present and Future of Halalan Toyyiban. Review of Integrative Business and Economics Research, 7(2), pp. 276-289.

[28] Demirbas, A. (2011). Waste management, waste resource facilities and waste conversion processes. Energy Conversion and Management, 52(2), pp. 1280-1287. https://doi.org/10.1016/j.enconman.2010.09.025

[29] Department of Islamic Development Malaysia (JAKIM). (2014). Manual Procedure for Malaysia Halal Certification (Third Revision), pp. 1-67.

[30] Department of Standards Malaysia. (2014). Halal packaging-General guidelines (MS 2565:2014), pp. 1-9.

[31] Department of Standards Malaysia. (2019a). Halal food - General requirements (Third revision) (MS 1500: 2019), pp. 1-12.

[32] Department of Standards Malaysia. (2019b). Halal supply chain management system- Part 1: Transportation- General Requirements (MS 2400-1:2019), pp. 1-32

[33] Deuraseh, N. (2019). Halalan Toyyiban Products in Al- Qur'an: The Conceptual Framework in Developing Contemporary Halal Industrial Products for Global Reach. In 1st International Halal Conference \& Exhibition 2019,1(1), pp. 315-325.

[34] DinarStandard. (2020). State of The Global Islamic Economy Report 2020/21. https://cdn.salaamgateway.com/reports/pdf/456642acf95a783db590e5b104cae940460471 01.pdf

[35] Eagle, L., \& Dahl, S. (2015). Marketing Ethics \& Society. SAGE Publications. 
https://books.google.com.my/books?id=9COJCwAAQBAJ

[36] Eames-Sheavly, M., Hadekel, C., McGregor Hedstrom, A., Patchen, A., Stewart, R., \& Wilkins, J. (2011). Discovering Our Food System: Experiential Learning \& Action for Youth and Their Communities. Cornell University Department of Horticulture, New York.

[37] Encyclopedia of Islam and the Muslim World. (n.d). "Tasawwuf". Retrieved July 14, 2020 fromhttps://www.encyclopedia.com/religion/encyclopedias-almanacs-transcripts-andmaps/tasawwuf

[38] Ericksen, P. J. (2008). Conceptualizing food systems for global environmental change research. Global Environmental Change, 18(1), pp. 234-245.

[39] Faurès, J. M., Bartley, D., Bazza, M., Burke, J., Hoogeveen, J., Soto, D., \& Steduto, P. (2013). Climate smart agriculture sourcebook. Food and Agriculture Organization on the United Nations, p570. http://www.fao.org/3/i3325e/i3325e.pdf

[40] Ghosh, P. R., Fawcett, D., Sharma, S. B., \& Poinern, G. E. J. (2016). Progress towards Sustainable Utilisation and Management of Food Wastes in the Global Economy. International Journal of Food Science, 2016, pp. 1-22. https://doi.org/10.1155/2016/3563478

[41] Grundey, D. (2010). Functionality of Product Packaging: Surveying Consumers' Attitude Towards Selected Cosmetic Brands. Economics \& Sociology, 3(1), pp. 87-103. https://doi.org/10.14254/2071-789x.2010/3-1/9

[42] Haqqi, A. R. A. (2017). The Administration of Halalan Toyyiban Products and Services in the Era of Islamic Caliphates under Hisbah Institution. Al-Iktisab: Journal of Islamic Economic Law, 1(2), p. 85. http://dx.doi.org/10.21111/al-iktisab.v1i2.2385

[43] Hashim, Y.Z.H-Y., \& Ahmad, A. N. (2020). Halal Toyyiban Dietary Practice for Good Health and Wellbeing. @Halal November/December 2020. https://view.joomag.com/halal-november-december-2020/0968682001605601207

[44] Hashim, Y.Z.H-Y., \& Salleh, M. H. (2020). Your F\&B is Halal, but is it Toyyib?. @ Halal Mac/April 2020. https://view.joomag.com/halal-march-april2020/0247988001586928763

[45] Hashim, Y. Z. H-Y., Ahmad, A. N., \& Hamzah, M. S. (2020). Halalan Toyyiban diet- a way forward. @Halal Sept-Oct, 2020, pp. 20-21.

[46] Hassan, M. H., Arif, S., \& Sidek, S. (2015). Knowledge and Practice for Implementing Internal Halal Assurance System among Halal Executives. Asian Social Science, 11(17).

[47] Hinrichs, C. C. (2000). Embeddedness and local food systems: notes on two types of direct agricultural market. Journal of Rural Studies, 16(3), pp. 295-303. https://doi.org/10.1016/S0743-0167(99)00063-7

[48] HLPE. (2014). Food losses and waste in the context of sustainable food systems. A report by the High Level Panel of Experts on Food Security and Nutrition of the Committee on World Food Security, Rome 2014. 4. http://www.fao.org/3/a-i3901e.pdf

[49] Ishak, M. S. B. H., \& Abdullah, O. C. (2012). Islamic perspective on marketing mix. International Journal of Business and Management Studies, 4(1), 121-131. https://www.researchgate.net/publication/292566564_Islamic_Perspective_on_Marketing -Mix

[50] Islamic Finance. (2014, April 30). Does Halal financing have a limited shelf-life?. Islamic Finance news, 11(17), 2. http://islamicfinancenews.com/sites/default/files/newsletters/v11i17.pdf

[51] Janjarasskul, T., \& Suppakul, P. (2018). Active and intelligent packaging: The indication 
of quality and safety. Critical Reviews in Food Science and Nutrition, 58(5), pp. 808-831. https://doi.org/10.1080/10408398.2016.1225278

[52] Kohilavani, Zzaman, W., Febrianto, N. A., Zakariya, N. S., Abdullah, W. N. W., \& Yang, T. A. (2013). Embedding Islamic dietary requirements into HACCP approach. Food Control, 34(2), pp. 607-612. https://doi.org/10.1016/j.foodcont.2013.06.008

[53] Liow, RJ (2016). "Marketing Halal: Creating New Economy. New Wealth" Hands on Experience By an Award Winning Non-Muslim Halal Entrepreneur. International Journal of Financial Management (IJFM), 5(2), pp. 55-68.

[54] Loong, C. (2013). Information on Food Labelling Requirements in Malaysia. pp. 1-15 https://www.mfca.org.my/articles/Information\%20on\%20Food\%20Labeling\%20Require ments\%20in\%20Malaysia.pdf

[55] Loucanova, E., Kalamarova, M., \& Parobek, J. (2017). The Innovative Approaches to Packaging - Comparison Analysis of Intelligent and Active Packaging Perceptions in Slovakia. Studia Universitatis Economic Series, 27(2), pp. 33-44. https://doi.org/10.1515/sues-2017-0007

[56] Mahalik, N. P., \& Nambiar, A. N. (2010). Trends in food packaging and manufacturing systems and technology. Trends in Food Science \& Technology, 21(3), pp. 117-128. https://doi.org/10.1016/j.tifs.2009.12.006

[57] Maretzki, A. N., \& Tuckermanty, E. (2007). Community Food Projects and Food System Sustainability. In Hinrichs. CC, \& Lyson. TA (Eds.), Remaking the North American Food System (p. 332). Lincoln: University of Nebraska Press.

[58] Ministry of Health Malaysia. (2020). FAQ. Healthier Choice Logo (HCL). Retrieved November 8, 2020, from http://myhcl.moh.gov.my/index.php/site/faq

[59] Mohamad, M. H. (2019, September 4). Halal consumerism from a wider perspective. The New Straits Times. https://www.nst.com.my/opinion/columnists/2019/09/518767/halal-consumerism-widerperspective

[60] Mohamad, N. S., \& Khairuldin, W. M. K. F. W. (2018). The Concept of Halalan Toyyiba in Food According to Mufassir. International Journal of Academic Research in Business and Social Sciences, 8(11), pp. 902-909.

[61] Muhammad Mushfique. (2018, January 10). Al-Kahfi \#687 Haiwan-haiwan yang dilarang untuk dimakan di dalam Islam. Official Website Mufti of Federal Territory. https://muftiwp.gov.my/en/artikel/al-kafi-li-al-fatawi/2210-al-kafi-687-haiwan-haiwanyang-haram-untuk-dimakan-di-dalam-islam

[62] Munib Siddiqui, Muhammad Ashraf Ali Farooqui, Hafsa Siddiqui, A. S. R. (2017). Halal Marketing (Islamic Principles of Marketing and Marketing Mix Model in Islam). 8th Global Islamic Marketing Conference Advances in Islamic Business, pp. 289-298. https://www.researchgate.net/publication/319140988_Halal_Marketing_Islamic_Principl es_of_Marketing_and_Marketing_Mix_Model_in_Islam

[63] National Coordinating Committee on Food and Nutrition. (2013). Malaysian Dietary Guidelines for Children and Adolescents. http://nutrition.moh.gov.my/wpcontent/uploads/penerbitan/buku/MDG_Children_adolescent_2014.pdf

[64] National Solid Waste Management Department, JPSPN, (2012). Food Waste Management Development Plan For Industry, Commercial and Institution Sector (2016-2026). https://jpspn.kpkt.gov.my/resources/index/user_1/Sumber_Rujukan/pelan_pembangunan 
_sismakanan/Food_waste_management_dev_plan_for_industry_commersial_and\%20inst itution_sector.pdf

[65] Neio Demirci, M., Soon, J. M., \& Wallace, C. A. (2016). Positioning food safety in Halal assurance. Food Control, 70, pp. 257-270. https://doi.org/10.1016/j.foodcont.2016.05.059

[66] Omar, S. M., Khan, A. J., \& Hashi, A. A. (2018). Islamic ethics of waste management towards sustainable environmental health. IIUM Medical Journal Malaysia, 17(Specialissue1), pp. 193-197. https://doi.org/10.31436/imjm.v17i1.1024

[67] Podsakoff, P. M., MacKenzie, S. B., \& Podsakoff, N. P. (2016). Recommendations for Creating Better Concept Definitions in the Organizational, Behavioral, and Social Sciences. Organizational Research Methods, 19(2), pp. 159-203. https://doi.org/10.1177\%2F1094428115624965

[68] Ravindran, R., \& Jaiswal, A. K. (2016). Exploitation of Food Industry Waste for HighValue Products. Trends in Biotechnology, 34(1), pp. 58-69. https://doi.org/10.1016/j.tibtech.2015.10.008

[69] Rezai, G., Mohamed, Z., \& Shamsudin, M. N. (2015). Can Halal Be Sustainable? Study on Malaysian Consumers' Perspective. Journal of Food Products Marketing, 21(6), pp. 654666. https://doi.org/10.1080/10454446.2014.883583

[70] Riza Ahmed, H. M., \& Monjur, M. (2010). Environmental Degradation : An Islamic Perspective. Social Science Reciew, 27(1), pp. 1-14.

[71] Ruslan, A. A. A., Kamarulzaman, N. H., \& Sanny, M. (2018). Muslim consumers' awareness and perception of Halal food fraud. International Food Research Journal, 25(Suppl. 1), pp. S87-S96.

[72] Salmon, S. J., Fennis, B. M., De Ridder, D. T. D., Adriaanse, M. A., \& De Vet, E. (2014). Health on impulse: When low self-control promotes healthy food choices. Health Psychology, 33(2), pp. 103-109.

[73] Shafiq, A., Haque, A., Abdullah K, J. M. (2017). Beliefs about Islamic advertising: an exploratory study in Malaysia. Journal of Islamic Marketing, 8(3), pp. 409-429.

[74] Siddique, R., Khatib, J., \& Kaur, I. (2008). Use of recycled plastic in concrete: A review. Waste Management, 28(10), pp. 1835-1852. https://doi.org/10.1016/j.wasman.2007.09.011

[75] Siddiqui, R. (2014, September 28). Opinion: Moving from halal to Toyyib. HalalFocus.net - Daily Halal Market News. https://halalfocus.net/opinion-moving-from-halal-to-Toyyib/

[76] Sira, A. R. (2017). Religion and animal welfare - An Islamic perspective. Animals, 7(2), pp. 1-6. https://dx.doi.org/10.3390\%2Fani7020011

[77] Sobal, J., Khan, L. K., \& Bisogni, C. (1998). A conceptual model of the food and nutrition system. Social science \& medicine (1982), 47(7), pp. 853-863. https://doi.org/10.1016/s0277-9536(98)00104-X

[78] Sonneveld, K., James, K., Fitzpatrick, L., \& Lewis, H. (2005). Sustainable Packaging: How do we Define and Measure It?.Symposium A Quarterly Journal in Modern Foreign Literatures, (April), pp. 1-9.

[79] Soon, J. M., Mahmood, C., Regenstein, J. M. (2017). Halal integrity in the food supply chain. British Food Journal, 119(1), pp. 39-51. https://doi.org/10.1108/BFJ-04-2016-0150

[80] Sulaiman, A., Othman, N., Baharuddin, A. S., Mojkhtar, M. N., \& Tabatabei, M. (2014). Enhancing the Halal Food Industry by Utilizing Food Wastes to Produce Value-added Bioproducts. Procedia- Social and Behavioral Sciences, 121, pp. 35-43. https://doi.org/10.1016/j.sbspro.2014.01.1106 
[81] Sungit, F., Isa, M., Deni, M., Abdullah, M., \& Putra, B. S. (2020). Concepts and Practices of Halalan Toyyiban in the Islamic Manufacturing Practice (IMP): An Analysis from Syariah Perspective. Journal of Social Sciences and Humanities, 2600(7274), pp. 214-229.

[82] Talib, M. S. A., \& Johan, M. R. M. (2012). Issues in Halal Packaging: A Conceptual Paper. International Business and Management, 5(2), pp. 94-98. https://doi.org/10.3968/j.ibm.1923842820120502.1080

[83] Tieman, M. (2011). The application of Halal in supply chain management: In-depth interviews. Journal of Islamic Marketing, 2(2), pp. 186-195. https://doi.org/10.1108/17590831111139893

[84] Tieman, M., van der Vorst, J. G. A. J., \& Ghazali, M. C. (2012). Principles in halal supply chain management. Journal of Islamic Marketing, 3(3), pp. 217-243. https://doi.org/10.1108/17590831211259727

[85] United Nations General Assembly. (2015). Transforming Our World: the 2030 Agenda for Sustainable Development Goals- Zero Hunger (Goal Number 2). https://sustainabledevelopment.un.org/sdg2

[86] Wan Harun, M. A. (2016). Halalan Toyyiba model based on Quranic mufasir exegesis (Model Halalan Toyyiba berdasarkan tafsiran istilah sarjana mufasir Al Quran). Sains Humanika, 8:3-2, pp. 13-20. https://doi.org/10.11113/sh.v8n3-2.959

[87] Zailani, S., Jafarzadeh, S., Iranmanesh, M., Nikbin, D., \& Selim, N. I. I. (2018). Halal logistics service quality: conceptual model and empirical evidence. British Food Journal, 120(11), pp. 2599-2614. https://doi.org/10.1108/BFJ-07-2017-0412

[88] Zainol, Z., Yahaya, R., Osman, J., \& Omar, N. A. (2020). Application of the Toyyib concept among Malaysian muslim consumers: The role of nutrition label. Journal of Islamic Marketing, 11(3), pp. 819-840. https://doi.org/10.1108/JIMA-03-2018-0048)

[89] Zakaria, Z. (2008). Tapping into the World Halal Market: Some Discussions on Malaysian Laws and Standards. Jurnal Syariah, 16(3), pp. 603-616. 